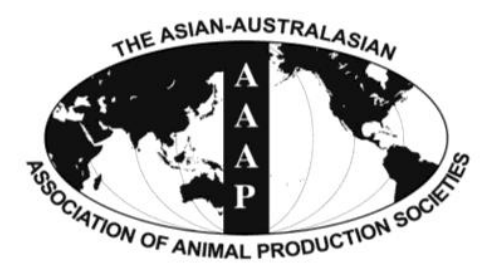

Asian-Aust. J. Anim. Sci.

Vol. 25, No. 3 : 335 - 340

March 2012

www.ajas.info

http://dx.doi.org/10.5713/ajas.2011.11220

\title{
The Influence of Dietary Characteristics on the Milk Quantity and Quality of Riverine Buffaloes: Estimate of the Energy/Protein Requirements, for a Medium-high Production, in the First Ninety Days of Lactation
}

\author{
S. Terramoccia*, A. Bartocci, S. Di Giovanni and S. Bartocci \\ CRA-PCM (Centro di Ricerca per la Produzione delle Carni e il Miglioramento Genetico), \\ 00015 Monterotondo, Rome, Italy
}

\begin{abstract}
The data used came from two trials undertaken under the same climatic conditions (spring-summer). In both trials pluriparious buffaloes were utilized similar in weight, body condition score, and milk production from the previous year. From the first trial the data used was from the sub-period 23-88 DIM provided by seven animals fed ad libitum with diet A (6.69 MJ/kg DM; 158.30 $\mathrm{g} / \mathrm{kg}$ of crude protein) with a forage/concentrate ratio of 48/52. From the second trial the data used was from the sub-period 33-90 DIM provided by seven animals fed ad libitum with diet B (6.63 MJ/kg DM; $179.50 \mathrm{~g} / \mathrm{kg}$ of crude protein) and by seven animals fed ad libitum with diet C (5.99 MJ/kg DM; $155.40 \mathrm{~g} / \mathrm{kg}$ of crude protein), each of the diets had the same forage/concentrate ratio (53/47). A significant difference was found in milk production between group B and C (13.08 vs. $11.56 \mathrm{~kg} / \mathrm{d}, \mathrm{p}<0.05)$, an intermediate production $(12.10 \mathrm{~kg} / \mathrm{d})$ was noted in group A. A significant difference was found between fat (76.58 vs. $69.24 \mathrm{~g} / \mathrm{kg}, \mathrm{p}<0.05)$, protein $(46.14 \mathrm{vs}$. $43.16 \mathrm{~g} / \mathrm{kg}, \mathrm{p}<0.05)$ and casein $(39.94 \mathrm{vs.} 34.98 \mathrm{~g} / \mathrm{kg}, \mathrm{p}<0.05)$ of the milk of group B with respect to group A. The milk of group C gave fat values $(71.80 \mathrm{~g} / \mathrm{kg})$, protein $(45.52 \mathrm{~g} / \mathrm{kg})$ and casein $(39.06 \mathrm{~g} / \mathrm{kg})$ statistically equal to those of group B. The milk of groups B and C, in respect to the milk of group $A$, gave values of $\mathrm{K}_{20}(1.77,1.82 \mathrm{vs.} 3.68 \mathrm{~min}, \mathrm{p}<0.05)$, statistically lower and values of $\mathrm{A}_{30}(48.28,47.27$ vs. $40.64 \mathrm{~mm}, \mathrm{p}<0.05)$ statistically higher. Two simple linear regressions were calculated where the independent variable ( $\mathrm{x}$ ) was the daily standardized milk production, the dependent variable (y) or the daily intake of net energy or crude protein. Equation 1) NE (MJ/d) $=74.4049+2.8308 \times \mathrm{kg}$ of normalized milk; equation 2) $\mathrm{CP}(\mathrm{kg} / \mathrm{d})=1.4507+0.1085 \times \mathrm{kg}$ of normalized milk, both the equations were significant $(\mathrm{p}<0.05)$ with determination coefficients of 0.58 and 0.50 respectively. For a production of normalized milk that varies from 9 to $13 \mathrm{~kg}$, the respective energy-protein concentrations fluctuate from 6.09 to $6.78 \mathrm{MJ} / \mathrm{kg} \mathrm{DM}$ and from 148.00 to $174.46 \mathrm{~g} / \mathrm{kg} \mathrm{DM}$. (Key Words : Buffalo, Milk Quantity and Quality, Energy-protein Requirements)
\end{abstract}

\section{INTRODUCTION}

The buffalo species is bred on all continents, in a variety of geographical, environmental and agronomic contexts with different methods and aims; this has led to marked differences in the diets adopted. In Western Europe its diet is based on forages, silage, byproducts and concentrates (Bartocci et al., 2002a). In order to estimate the requirements of the lactating buffalo, also verifying the effect of the diets used on the milk quality (Tripaldi, 1994), diets with medium-low energy/protein levels were used (Verna et al., 1993a; Verna et al., 1993b; Verna et al., 1994)

\footnotetext{
* Corresponding Author : S. Terramoccia. Tel : +39-6-900901, Fax : +39-6-9061541, E-mail : stefano.terramoccia@entecra.it Submitted Jul. 11, 2011; Accepted Sept. 15, 2011; Revised Oct. 24, 2011
}

taking into consideration also the protein level suggested by Rai and Aggarwal (1991). The results obtained, confirmed also by Bertoni and Piccioli Cappelli (1994), showed that the different energy-protein levels used did not significantly increase milk production. In Italy the supply of buffalo milk, used exclusively for cheese production, has always been lower than the demand, this has led to an expansion of this species, also substituting the bovine species, with an improvement in the technologies used and has contributed to the opinion that the improvement of milk production could be achieved by increasing energy and crude protein intake (Sarrubi et al., 2000). Bartocci et al. (2006), administering a high energy-protein level, attained a significant effect on milk production without the animals displaying negative metabolic or physiologic symptoms. In 
a subsequent work (Bartocci and Terramoccia, 2010), maintaining constant the energy level of the two diets of the earlier work, but increasing the protein level, obtained positive production results and showed that each of the two diets studied could be used advantageously in two different lactation periods. As a consequence of these results, the need arose to define energy/protein requirements for medium-high production in the first ninety days of lactation. Further research was undertaken on twenty farms in order to verify the effects of the diets used on the chemical and technological characteristics of the milk produced (Bartocci et al., 2002a; Tripaldi et al., 2002; Tripaldi et al., 2003). Some Authors (Zicarelli, 2000; Bartocci et al., 2002a; Bartocci et al., 2002b) have provided indications with regard to the requirements of the lactating buffalo, but exclusively with regard to production and unrelated to the stage of lactation, but the administration of diets rich in starch and fermentable carbohydrates, at an inappropriate stage of lactation, facilitates excessive fattening and due to an increase in insulin, leads to a reduction in the lactation period (Bartocci et al., 2002b).

The aim of this work is to define: i) the appropriate energy-protein level to obtain an increased quantity of milk of higher quality, ii) the estimate of energy-protein requirements for a medium to high production in the first ninety days of lactation.

\section{MATERIALS AND METHODS}

\section{Animals and diets}

Data from two earlier trials were used: the first Bartocci et al. (2006), the second Bartocci and Terramoccia (2010). The two studies were undertaken under the same climatic conditions (spring-early summer), using, in both trials, pluriparous buffaloes similar in weight, stage of fattening and with regard to average production of the preceding year; the same type of feed: 2nd cut alfalfa hay, maize silage and a specifically formulated concentrate was used for each diet. In both trials the animals were divided into two groups of seven buffaloes fed on an ad libitum basis; the feed was given as a mixed ration once a day, but the feeding was on an individual basis in the first trial, and on a group basis in the second. Milking was undertaken twice a day at 12-h intervals, individual production was checked every two weeks and then representative milk samples of the two milkings were taken for analytical determinations. The first trial lasted 114 days and the second 116 days. For this research, the data from two sub-periods was used: 2388 DIM (Bartocci et al., 2006) and 33-90 DIM (Bartocci and Terramoccia, 2010). For the first sub-period individual data was used from seven animals fed with diet A which had a forage/concentrate ratio of $48 / 52$ with the following formula: 2 nd cut alfalfa hay $=10 \%$, maize silage $=38 \%$, concentrate $=52 \%(6.69 \mathrm{MJ} / \mathrm{kg} \mathrm{DM} ; 158.3 \mathrm{~g} / \mathrm{kg} \mathrm{DM}$ of crude protein). The data appertaining to the seven animals fed with the second diet $(6.05 \mathrm{MJ} / \mathrm{kg} \mathrm{DM} ; 144.4 \mathrm{~g} / \mathrm{kg} \mathrm{DM}$ of crude protein) was discarded since the milk production was not considered satisfactory due to its substandard protein level. From the second trial, the individual data of seven animals from both the diets (B and C) was used, these diets both had the same forage/concentrate ratio 53/47 but with different percentages of the two forages, precisely diet B: 2 nd cut alfalfa hay $=10 \%$, maize silage $=43 \%$, concentrate $=47 \%(6.63 \mathrm{MJ} / \mathrm{kg} \mathrm{DM} ; 179.5 \mathrm{~g} / \mathrm{kg} \mathrm{DM}$ of crude protein); diet C: 2 nd cut alfalfa hay $=20 \%$, maize silage $=33 \%$, concentrate $=47 \%(5.99 \mathrm{MJ} / \mathrm{kg} \mathrm{DM} ; 155.4$ $\mathrm{g} / \mathrm{kg}$ DM of crude protein). The net energy of the feedstuffs, expressed as $\mathrm{MJ} / \mathrm{kg} \mathrm{DM}$, was determined using the chemical composition and the digestibility of the organic substance (INRA, 1988).

\section{Chemical analyses}

Table 1 presents the chemical composition and net

Table 1. Dry matter (g/kg as fed), chemical composition (g/kg DM) and net energy (MJ/kg DM) of feedstuffs utilized in experimental diets

\begin{tabular}{|c|c|c|c|c|c|c|c|c|c|}
\hline & $\overline{\mathrm{DM}}$ & $\mathrm{CP}$ & $\mathrm{CF}$ & $\mathrm{EE}$ & $\overline{\mathrm{NSC}}$ & Ash & NDF & $\mathrm{ADF}$ & $\mathrm{NE}$ \\
\hline Maize silage $\mathrm{A}$ & 313.9 & 72.4 & 186.5 & 33.0 & 388.2 & 44.4 & 462.0 & 248.6 & 5.97 \\
\hline Maize silage $\mathrm{B}$ and $\mathrm{C}$ & 298.4 & 81.5 & 269.9 & 25.5 & 263.1 & 62.0 & 567.9 & 347.1 & 5.69 \\
\hline Alfalfa hay A, 2nd cut & 887.0 & 140.3 & 339.7 & 18.0 & 229.9 & 81.6 & 530.2 & 366.3 & 4.27 \\
\hline Alfalfa hay B and C, 2nd cut & 884.6 & 149.3 & 396.6 & 12.0 & 255.4 & 89.8 & 493.5 & 455.3 & 4.69 \\
\hline Concentrate A & 897.9 & 224.7 & 67.7 & 31.4 & 472.5 & 85.9 & 185.5 & 74.4 & 7.68 \\
\hline Concentrate B & 901.8 & 275.7 & 72.5 & 26.9 & 437.8 & 86.1 & 173.5 & 89.1 & 7.90 \\
\hline Concentrate C & 905.3 & 209.9 & 120.3 & 29.6 & 375.5 & 90.1 & 294.9 & 147.2 & 6.76 \\
\hline Diet A & 674.9 & 158.3 & 140.4 & 30.6 & 416.5 & 69.6 & 325.0 & 169.8 & 6.69 \\
\hline Diet B & 640.6 & 179.5 & 189.8 & 24.8 & 344.5 & 76.1 & 375.1 & 236.7 & 6.63 \\
\hline Diet C & 700.9 & 155.4 & 224.9 & 24.7 & 314.4 & 80.8 & 424.7 & 274.8 & 5.99 \\
\hline
\end{tabular}

$\mathrm{DM}=$ Dry matter; $\mathrm{CP}=$ Crude protein $; \mathrm{CF}=$ Crude fibre; $\mathrm{EE}=$ Ether extract; $\mathrm{NSC}=$ Non-structural carbohydrates;

$\mathrm{NDF}=$ Neutral-detergent fibre; $\mathrm{ADF}=$ Acid-detergent fibre; $\mathrm{NE}=$ Net energy.

Composition on DM basis for Diet $\mathrm{A}(\mathrm{F}: \mathrm{C}=48: 52)$ : maize silage $=38 \%$, alfalfa hay $=10 \%$, concentrate $\mathrm{A}=52 \%$,

Composition on DM basis for Diet B ( $\mathrm{F}: \mathrm{C}=53: 47)$ : maize silage $=43 \%$, alfalfa hay $=10 \%$, concentrate $\mathrm{B}=47 \%$.

Composition on DM basis for Diet C ( $\mathrm{F}: \mathrm{C}=53: 47)$ : maize silage $=33 \%$, alfalfa hay $=20 \%$, concentrate $\mathrm{C}=47 \%$. 
energy of the feedstuffs and diets used. Samples of the forages and concentrates, frequently collected, were subjected to the following chemical analyses: dry matter (DM), crude protein (CP), crude fibre (CF), ether extract (EE) and ash according to the methods of the Association of Official Analytical Chemists (AOAC, 1995), neutral detergent fibre (NDF) and acid detergent fibre (ADF) according to the Goering and Van Soest method (1970). In addition the non-structural carbohydrates (NSC) were calculated as reported by Van Soest et al. (1991). The individual milk samples representative of the yield of the two milkings, underwent the following analytical determinations: $\mathrm{pH}$, fat, protein $(\mathrm{N} \times 6.38)$, casein (ASPA, 1995). The three parameters of the milk coagulation were established: rennet clotting time (r), curd firming time $\left(\mathrm{K}_{20}\right)$, curd firmness $\left(\mathrm{A}_{30}\right)$ by means of the thromboelastograph Formagraph (Zannoni and Annibaldi, 1981). The production of mozzarella cheese was estimated by using the equation proposed by Altiero et al. (1989).

\section{Statistical analyses}

The differences between groups were tested utilizing the GLM/SAS procedure (SAS, 1993) with a monofactorial model. In order to estimate the energy-protein requirements of the buffalo, in the first 90 days of lactation, both the data from the first study and from the second study were utilized, using a simple linear regression REG/SAS procedure (SAS, 1993). The independent variable (x) was the daily milk production normalized to the same percentage in fat $(83.00$ $\mathrm{g} / \mathrm{kg}$ ) and in protein $(47.30 \mathrm{~g} / \mathrm{kg})$, the dependent variable (y) was the daily intake of net energy and crude protein.

\section{RESULTS AND DISCUSSION}

\section{Milk yield and milk quality}

The average weight of the animals in each group was similar: $670.5,677.9$ and $661.4 \mathrm{~kg}$, respectively for group A, $\mathrm{B}$ and $\mathrm{C}$; the average weight of all the buffaloes was 669.9 $\mathrm{kg}$. The average daily weight gain was $8 \mathrm{~g} / \mathrm{d}$ in group $\mathrm{A}$, $252 \mathrm{~g} / \mathrm{d}$ in $\mathrm{B}$ and $160 \mathrm{~g} / \mathrm{d}$ in $\mathrm{C}$, with an average of $140 \mathrm{~g} / \mathrm{d}$. The intake of dry matter by the buffaloes who used diets B and $\mathrm{C}$ was almost identical (16.61 and $16.59 \mathrm{~kg}$ ), and that of group A was similar (16.00 kg); resulting in an average intake of $16.40 \mathrm{~kg}$, that represents $2.45 \%$ of the average weight of all the animals involved. Therefore, according to the results reported by Bartocci et al. (2006) and confirmed by Bartocci and Terramoccia (2010), it can be affirmed that the different energy-protein level of the diets used in these trials has not modified the quantity of dry matter ingested; in addition, the ingestion capacity detected has been confirmed by various Authors (Ranijhan, 1992; Bertoni and Piccioli Cappelli, 1994; Verna et al., 1994; Bartocci et al., 2002a). The net energy of diets A, B and C was 6.69, 6.63 and $5.99 \mathrm{MJ} / \mathrm{kg} \mathrm{DM}$ with an average daily ingestion of
107.04, 110.12 and $99.37 \mathrm{MJ}$; the protein content was 158.3, 179.5 and $155.4 \mathrm{~g} / \mathrm{kg} \mathrm{DM}$, with an average daily ingestion of $2.53,2.98$ and $2.58 \mathrm{~kg}$.

As can be seen in Table 2, in the first ninety days of lactation, it has been noted that $\operatorname{diet} \mathrm{B}$ had a significant effect on the quantity of milk produced in comparison to diet $\mathrm{C}(13.08$ vs. $11.56 \mathrm{~kg} / \mathrm{d}, \mathrm{p}<0.05)$, the production ascertained for diet A had an intermediate trend $(12.20 \mathrm{~kg} / \mathrm{d})$. Therefore increasing the energy content, from 5.99 to 6.69 $\mathrm{MJ} / \mathrm{kg} \mathrm{DM}$, and in a limited measure that of protein, from 155.4 to $158.3 \mathrm{~g} / \mathrm{kg} \mathrm{DM}$ (diet C vs. A), no significant increase in milk production was obtained (11.56 and 12.20 $\mathrm{kg} / \mathrm{d}$ ); but only when there is an increase not only of the energy level, from 5.99 to $6.63 \mathrm{MJ} / \mathrm{kg} \mathrm{DM}$, but also of the protein level, from 155.4 to $179.5 \mathrm{~g} / \mathrm{kg} \mathrm{DM}$, (diets C vs. B) is a significantly higher milk production obtained. From the results obtained, what has already been stated by Campanile et al. (1998) and by Bartocci et al. (2006) can be confirmed, and that is that in the first phase of lactation, with an energy concentration of $6.05 \mathrm{MJ} / \mathrm{kg} \mathrm{DM}$ the protein concentration must not be less than $150 \mathrm{~g} / \mathrm{kg} \mathrm{DM}$ and it can also be affirmed that with an energy concentration of $6.69 \mathrm{MJ} / \mathrm{kg}$ DM the protein concentration must not be less than 170 $\mathrm{g} / \mathrm{kg}$ DM. The lactating buffalo, even with diets with high protein levels, would be able to maintain a substantially constant blood urea rate and the use of such diets would not prove damaging to the animals (Zicarelli, 2000; Infascelli, 2003).

It can be noted, when considering diet $\mathrm{B}$ in respect to $\operatorname{diet} \mathrm{A}$, that there is a significant increase in the fat content (76.58 vs. $69.24 \mathrm{~g} / \mathrm{kg}, \mathrm{p}<0.05$ ), protein (46.14 vs. 43.16 $\mathrm{g} / \mathrm{kg}, \mathrm{p}<0.05)$ and casein $(39.94$ vs. $34.98 \mathrm{~g} / \mathrm{kg}, \mathrm{p}<0.05)$ in the milk; diet $\mathrm{C}$ generated the production of a milk with an intermediate fat content $(71.80 \mathrm{~g} / \mathrm{kg})$ but with a protein $(45.52 \mathrm{~g} / \mathrm{kg})$ and casein content $(39.06 \mathrm{~g} / \mathrm{kg})$ statistically equal to that of milk B. Therefore the buffaloes fed with diet $\mathrm{B}$, with a greater energy-protein concentration and a

Table 2. Milk yield and quality, estimated yield of mozzarella cheese

\begin{tabular}{lcccc}
\hline & Group A & Group B & Group C & Rmse \\
\hline Milk yield $(\mathrm{kg} / \mathrm{d})$ & $12.20^{\mathrm{ab}}$ & $13.08^{\mathrm{a}}$ & $11.56^{\mathrm{b}}$ & 1.16 \\
Fat $(\mathrm{g} / \mathrm{kg})$ & $69.24^{\mathrm{b}}$ & $76.58^{\mathrm{a}}$ & $71.80^{\mathrm{ab}}$ & 5.37 \\
Protein $(\mathrm{g} / \mathrm{kg})$ & $43.16^{\mathrm{b}}$ & $46.14^{\mathrm{a}}$ & $45.52^{\mathrm{a}}$ & 1.93 \\
Casein $(\mathrm{g} / \mathrm{kg})$ & $34.98^{\mathrm{b}}$ & $39.94^{\mathrm{a}}$ & $39.06^{\mathrm{a}}$ & 2.36 \\
$\mathrm{pH}$ & 6.93 & 6.83 & 6.89 & 0.10 \\
$\mathrm{r}(\min )$ & 17.50 & 18.44 & 19.09 & 2.92 \\
$\mathrm{~K}_{20}(\mathrm{~min})$ & $3.68^{\mathrm{a}}$ & $1.77^{\mathrm{b}}$ & $1.82^{\mathrm{b}}$ & 0.58 \\
$\mathrm{~A}_{30}(\mathrm{~mm})$ & $40.64^{\mathrm{b}}$ & $48.48^{\mathrm{a}}$ & $47.27^{\mathrm{a}}$ & 5.65 \\
Estimated mozzarella & $2.77^{\mathrm{B}}$ & $3.22^{\mathrm{A}}$ & $2.70^{\mathrm{B}}$ & 0.26 \\
cheese $(\mathrm{kg} / \mathrm{d})$ & & & & \\
\hline
\end{tabular}

${ }^{\mathrm{A}, \mathrm{B}} \mathrm{p}<0.01 ;{ }^{\mathrm{a}, \mathrm{b}} \mathrm{p}<0.05$. 
protein/energy ratio equal to 27.07 , produce a milk with levels not significantly different from the milk produced by the buffaloes fed with diet $\mathrm{C}$, with a lower energy-protein concentration but with a similar protein/energy ratio (25.94). Diet A with an energy content similar to that of diet B and a protein content similar to that of $\operatorname{diet} \mathrm{C}$ and a lower protein/energy ratio (23.66) generates the production of a milk of inferior quality. Some Authors (Bertoni et al., 1994; Bartocci et al., 2002a) have highlighted that with an increased intake of concentrate in the diet, milk with a higher protein and lipid content is obtained.

The $\mathrm{pH}$ of the three milks 6.93, 6.83 and 6.89 (diets A, $\mathrm{B}$ and $\mathrm{C})$ presents no significant differences. Taking into account the three coagulation parameters, if between the three rennet clotting times ( $r$ ) there is no significant difference $(17.50,18.44$ and $19.08 \mathrm{~min})$, the values of the curd firming time $\left(\mathrm{K}_{20}\right)$ are lower and statistically different for milks B and C with respect to milk A $(1.77,1.82$ vs. $3.68 \mathrm{~min}, \mathrm{p}<0.05)$; on the contrary the values of the curd firmness $\left(\mathrm{A}_{30}\right)$ are statistically higher for milks $\mathrm{B}$ and $\mathrm{C}$ with respect to milk A (48.28, 47.27 vs. $40.64 \mathrm{~mm}, \mathrm{p}<0.05)$. On the basis of these results it can be asserted that the milk produced from the diets $\mathrm{B}$ and $\mathrm{C}$, as well as better composition, also has a better potential for cheesemaking because of its lower value of $K_{20}$ and its higher value of $A_{30}$. Milk B provides an estimated production of mozzarella considerably higher than milks A and C (3.22 vs. $2.77,2.70$ $\mathrm{kg} / \mathrm{d}, \mathrm{p}<0.05$ ), but it should be highlighted that the quantity of mozzarella produced daily with milks $\mathrm{A}$ and $\mathrm{C}$ is almost the same.

These results indicate that in the first 90 days of lactation, utilizing a diet with a high energy/protein level, it is possible to improve the milk quantity and quality, without metabolic and physiological problems and with limited fattening.

\section{Energy-protein requirements for medium-high yield in the first 90 days of lactation}

Table 3 records two regression equations, in the first (y) represents the daily intake of net energy $(\mathrm{MJ} / \mathrm{d})$, in the second that of crude protein $(\mathrm{kg} / \mathrm{d})$, both with respect to the
Table 3. Regression equations between intake of net energy or crude protein $(\mathrm{y})$ and quantity of normalized milk produced $(\mathrm{x})$

\begin{tabular}{lrccl}
\hline & $\mathrm{a}$ & $\mathrm{b}$ & $\mathrm{R}^{2}$ & Rmse \\
\hline $\mathrm{NE}(\mathrm{MJ} / \mathrm{d})$ & 74.4049 & 2.8308 & $0.58^{*}$ & 3.13 \\
$\mathrm{CP}(\mathrm{kg} / \mathrm{d})$ & 1.4507 & 0.1085 & $0.50^{*}$ & 0.14 \\
\hline
\end{tabular}

* $\mathrm{p}<0.05$.

daily production of normalized milk (x):

$$
\begin{aligned}
& \mathrm{NE}(\mathrm{MJ} / \mathrm{d})=74.4049+2.8308 \times \mathrm{kg}_{\text {milk }} \\
& \mathrm{CP}(\mathrm{kg} / \mathrm{d})=1.4507+0.1085 \times \mathrm{kg}_{\text {milk }}
\end{aligned}
$$

The two equations were significant $(\mathrm{p}<0.05)$ with determination coefficients of 0.58 and 0.50 respectively.

Table 4 presents estimated energy-protein requirements for a medium-high $(9-13 \mathrm{~kg}$ ) production of normalized milk (weight of the buffaloes $=670 \mathrm{~kg}$, daily gain $=140 \mathrm{~g}$, daily intake $=16.40 \mathrm{~kg} \mathrm{DM})$ in the first 90 days of lactation. From equations 1 and 2, the daily intake of net energy and crude protein was obtained varying the production of normalized milk from 9 to $13 \mathrm{~kg}$; dividing the daily intake of net energy obtained (99.88-111.20 MJ/d) or of crude protein $(2.43-2.86 \mathrm{~kg} / \mathrm{d})$ by the intake of dry matter $(16.40$ $\mathrm{kg} / \mathrm{d}$ ), an estimate is obtained of the energy-protein concentration of the diet in relation to the respective quantity of normalized milk produced. Therefore, for a normalized milk production that varies from 9 to $13 \mathrm{~kg} / \mathrm{d}$, the respective energy-protein concentration of the diet fluctuates from 6.09 to $6.78 \mathrm{MJ} / \mathrm{kg} \mathrm{DM}$ and from 148.00 to $174.46 \mathrm{~g} / \mathrm{kg}$ DM. From a thorough literature research, we were unable to locate any studies that document the energyprotein requirements of buffaloes in the first 90 days of lactation. Zicarelli (2000), Bartocci et al. (2002a) and Bartocci et al. (2002b) gave indications on energy-protein requirements with regard to the quantity of milk produced, neglecting the time elapsed since calving; this can lead to an excessive accumulation of weight and negative consequences of a metabolic or physiological nature. For a normalized milk production from 9 to $12 \mathrm{~kg} / \mathrm{d}$, Bartocci et

Table 4. Daily intake of net energy and crude protein in the first ninety days of lactation and indicative characteristics of rations ${ }^{1}$

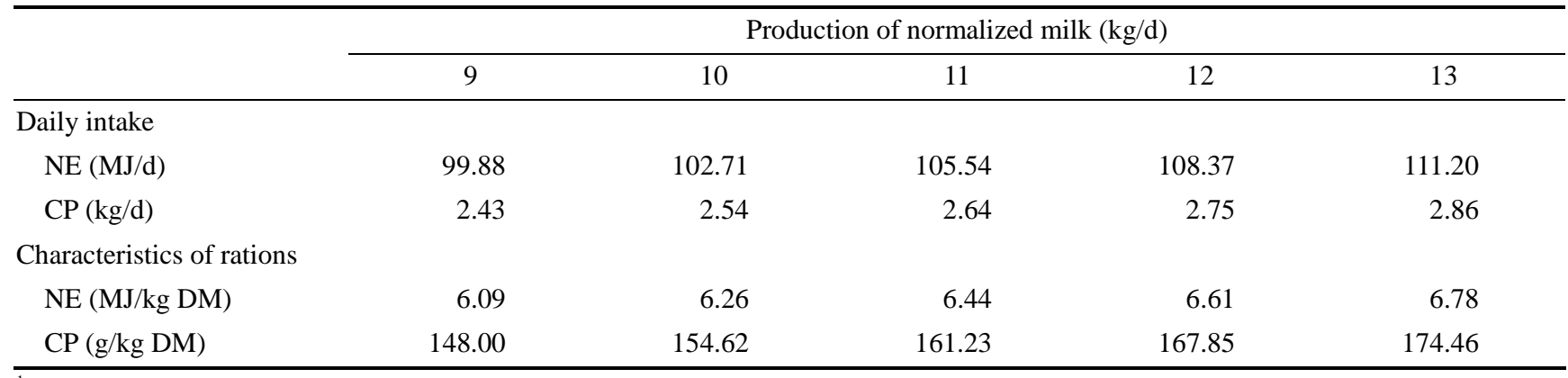

${ }^{1}$ Live weight $=670 \mathrm{~kg}$, Daily gain $=140 \mathrm{~g}$, Dry matter intake $=16.40 \mathrm{~kg} / \mathrm{d}$. 
al. (2002b) recommends an energy-protein concentration of the diet varying from 6.12 to $6.54 \mathrm{MJ} / \mathrm{kg} \mathrm{DM}$ and from 150.00 to $159.00 \mathrm{~g} / \mathrm{kg} \mathrm{DM}$ of crude protein, with a net energy intake from 95.47 to $111.18 \mathrm{MJ} / \mathrm{d}$ and crude protein from 2.34 to $2.70 \mathrm{~kg} / \mathrm{d}$; these results are obtained since the intake capacity of dry matter in relation to the energyprotein concentration of the diet was considered variable, from 15.60 to $17.00 \mathrm{~kg} / \mathrm{d}$. According to Bartocci et al. (2002a), processing data provided by buffalo farms during a survey, for a normalized milk production from 9 to $12 \mathrm{~kg} / \mathrm{d}$, the energy-protein concentration of the diet should vary from 5.62 to $6.33 \mathrm{MJ} / \mathrm{kg} \mathrm{DM}$ and from 121.27 to 150.76 $\mathrm{g} / \mathrm{kg} \mathrm{DM}$, with an average daily intake of $16.80 \mathrm{~kg} \mathrm{DM}$; this leads to a daily intake of net energy which fluctuates from 92.68 to $107.62 \mathrm{MJ} / \mathrm{d}$ and of crude protein from 2.00 to 2.56 $\mathrm{kg} / \mathrm{d}$. Zicarelli (2000), for a production of $10.64 \mathrm{~kg} / \mathrm{d}$ of normalized milk, specifies $100.00 \mathrm{MJ} / \mathrm{d}$ and $2.10 \mathrm{~kg} / \mathrm{d}$ of crude protein.

In order to define the quantity of net energy and crude protein necessary for the production of $1 \mathrm{~kg}$ of normalized milk, the requirements were considered, not only for the milk production, but also for the maintenance and weight variations of animals in the stall according to the indications reported by Zicarelli (2000). From the assessment undertaken it transpired that for the production of $1 \mathrm{~kg}$ of normalized milk, for diets fluctuating from 6.09 to 6.78 $\mathrm{MJ} / \mathrm{kg} \mathrm{DM}$ of net energy and from 148.00 to $174.46 \mathrm{~g} / \mathrm{kg}$ $\mathrm{DM}$ of crude protein, the net energy fluctuates from 5.55 to $4.76 \mathrm{MJ}$, the quantity of crude protein from 182 to $159 \mathrm{~g}$, with an average of $5.19 \mathrm{MJ}$ and $169 \mathrm{~g}$ of crude protein. Therefore, considering the constant increase in weight, augmenting the energy-protein concentration of the diet diminishes the quantity of energy and crude protein necessary for the production of $1 \mathrm{~kg}$ of normalized milk. The average values we reported are similar for net energy to those of Verna et al. (1994), Zicarelli (2000) and Bartocci et al. (2002a) but are higher for crude protein.

\section{CONCLUSIONS}

In the first 90 days of lactation, the quality of milk produced can be improved by using diets with an appropriate protein/energy ratio.

The energy-protein requirements for a medium-high production of normalized milk fluctuates from 9 to $13 \mathrm{~kg} / \mathrm{d}$, in the first 90 days of lactation, varies from 6.09 to 6.78 $\mathrm{MJ} / \mathrm{kg} \mathrm{DM}$ of net energy and from 148.00 to $174.46 \mathrm{~g} / \mathrm{kg}$ DM of crude protein; during this period, with these diets, the animals show no signs of metabolic or physiological problems.

Further studies should be undertaken in order to define the requirements of the buffalo in the second part of lactation.

\section{REFERENCES}

Altiero, V., L. Moio and F. Addeo. 1989. Estimate of mozzarella yield based on the fat and protein content of buffalo milk. Sci. Tec. Latt.-Casearia 40:425-433.

AOAC. 1995. Official methods of analysis, $16^{\text {th }}$ edn. Association of Official Analytical Chemists, Washington, DC.

ASPA. 1995. Methods of milk analysis of the main zootechnical species. Università degli Studi di Perugia, Italy.

Bartocci, S., C. Tripaldi and S. Terramoccia. 2002a. Characteristics of feedstuffs and diets, and the quantiqualitative milk parameters of Mediterranean buffaloes bred in Italy using the intensive system. An estimate of the nutritional requirements of buffalo herds lactating or dry. Livest. Prod. Sci. 77:45-58.

Bartocci, S., G. Campanile, F. Consalvo, E. Correale, A. Di Francia, V. Proto, S. Terramoccia and L. Zicarelli (Scientific committee of the consortium for the protection of Campania buffalo mozzarella cheese). 2002b. "Pattern of regulation for sanitary and feeding management of buffalo herds for the production of buffalo mozzarella cheese". Ed. Consorzio Tutela Mozzarella di Bufala Campana, S. Nicola la Strada (CE), Italy.

Bartocci, S., S. Terramoccia and C. Tripaldi. 2006. The utilisation of a high level energy/protein diet for lactating Mediterranean buffalo: Intake capacity and effects on quanti-qualitative milk parameters. Livest. Sci. 99:211-219.

Bartocci, S. and S. Terramoccia. 2010. Variations in the production, qualitative characteristics and coagulation parameters of the milk of the riverine buffalo determined by the energy/protein content of the diet. Asian-Aust. J. Anim. Sci. 23:1166-1173.

Bertoni, G. and F. Piccioli Cappelli. 1994. Effect of feeding on metabolic and productive conditions of buffaloes. Inf. Agrar. 18: 29-33.

Bertoni, G., T. Di Lella and S. Bartocci. 1994. Recent advances in buffalo nutrition. Agric. Ric. 153:159-179.

Campanile, G., C. De Filippo, R. Di Palo, W. Taccone and L. Zicarelli. 1998. Influence of dietary protein on urea levels in blood and milk of buffalo cows. Livest. Prod. Sci. 55:135-143.

Goering, H. K. and P. J. Van Soest. 1970. Forage fibre analysis (apparatus, reagents, procedures and some applications). ARS USDA Agriculture Hand Book $\mathrm{N}^{\circ} 379$, Washington, DC.

Infascelli, F. 2003. New acquisitions on the nutrition and feeding of buffalo. Atti $2^{\circ}$ Congresso nazionale sull'allevamento del bufalo. 28-30 Agosto 2003, Monterotondo-Roma, Italy, pp. 118.

INRA. 1988. Alimentation des bovins, ovins et caprins. INRA Publ., Paris, France.

Rai, S. N. and S. K. Aggarwal. 1991. Effect of substitution of green fodder with ammoniated straw on nutrient utilization and milk production in Murrah buffaloes. Buffalo J. 1:51-61.

Ranjhan, S. K. 1992. Nutrition of river buffaloes in Southern Asia. In: Buffalo Production (Ed. N. M. Thulloh and J. H. G. Holmes). Elsevier, Amsterdam, pp. 117-134.

SAS Statistical Analysis System Institute. 1993. SAS User's Guide, 
Statistics, SAS Institute Inc., Cary, NC, USA.

Sarubbi, F., T. Di Lella, G. Galiero, F. Infascelli, F. Bovera and G. Durante. 2000. Feeding diets varying in crude protein concentration and ruminal degradability to lactating Mediterranean buffalo cows. Zoot. Nutr. Anim. 26:181-188.

Tripaldi, C. 1994. Effetto di alcune diete sulle caratteristiche qualitative del latte di bufala. Agric. Ric. 153:79-86.

Tripaldi, C., S. Terramoccia and S. Bartocci. 2002. Attitudine del latte di bufala alla coagulazione presamica. Sci. Tec. Latt.Casearia 53:41-52.

Tripaldi, C., S. Terramoccia, S. Bartocci, M. Angelucci and V. Danese. 2003. The effects of the somatic cell count on yield, composition and coagulating properties of Mediterranean buffalo milk. Asian-Aust. J. Anim. Sci. 16:738-742.

Van Soest, P. J., J. B. Robertson and B. A. Lewis. 1991. Methods for dietary fiber, neutral detergent fiber and nonstarch polysaccharides in relation to animal nutrition. J. Dairy Sci. 74:3583-3597.
Verna, M., S. Bartocci, A. Amici and M. Agostini. 1993a. Effect of diets with different energetic concentration on the qualitative and quantitative yield in lactating buffaloes. In: Proceedings of the International Symposium on Prospects of Buffalo Production in the Mediterranean and the Middle East EAAP. Publication 62, pp. 258-261.

Verna, M., S. Bartocci, A. Amici and M. Agostini. 1993b. Prestazioni produttive di bufale in lattazione alimentate con diete a diversa concentrazione energetica e proteica. In: Proceeding of $10^{\text {th }}$ Congr. Naz. ASPA, pp. 247-252.

Verna, M., S. Bartocci, A. Amici and M. Agostini. 1994. Effect of different diets on productive performance of lactating buffaloes. Agric. Ric. 153:73-78.

Zannoni, M. and S. Annibaldi. 1981. Standardization of the renneting ability of milk by Formagraph. Sci. Tec. Latt.Casearia 32:79-94.

Zicarelli, L. 2000. Nutrition in dairy buffaloes. Ed. Università degli studi di Napoli Federico II. Facoltà di Medicina Veterinaria. 